\title{
Kinetic Analysis of Zinc/Cadmium Reciprocal Competitions Suggests a Possible Zn-Insensitive Pathway for Root-to- Shoot Cadmium Translocation in Rice
}

\author{
Laura Fontanili ${ }^{1 \dagger}$, Clarissa Lancilli, ${ }^{1,2}$, Nobuo Suzui ${ }^{3}$, Bianca Dendena ${ }^{1}$, Yong-Gen Yin ${ }^{3}$, Alessandro Ferri ${ }^{1}$, \\ Satomi Ishii ${ }^{3}$, Naoki Kawachi ${ }^{3}$, Giorgio Lucchini ${ }^{1}$, Shu Fujimaki ${ }^{3}$, Gian Attilio Sacchi ${ }^{1}$ and Fabio Francesco Nocito ${ }^{1^{*}}$
}

\begin{abstract}
Background: Among cereals, rice has a genetic propensity to accumulate high levels of cadmium (Cd) in grains. Xylem-mediated root-to-shoot translocation rather than root uptake has been suggested as the main physiological factor accounting for the genotypic variation observed in $\mathrm{Cd}$ accumulation in shoots and grains. Several evidence indicate OsHMA2 - a putative zinc ( $Z n)$ transporter - as the main candidate protein that could be involved in mediating $\mathrm{Cd}$ - and $\mathrm{Zn}$-xylem loading in rice. However, the specific interactions between $\mathrm{Zn}$ and $\mathrm{Cd}$ in rice often appear anomalous if compared to those observed in other staple crops, suggesting that root-to-shoot $\mathrm{Cd}$ translocation process could be more complex than previously thought. In this study we performed a complete set of competition experiments with $\mathrm{Zn}$ and $\mathrm{Cd}$ in order to analyze their possible interactions and reciprocal effects at the root-to-shoot translocation level.

Results: The competition analysis revealed the lack of a full reciprocity when considering the effect of $\mathrm{Cd}$ on $\mathrm{Zn}$ accumulation, and vice versa, since the accumulation of $\mathrm{Zn}$ in the shoots was progressively inhibited by $\mathrm{Cd}$ increases, whereas that of $\mathrm{Cd}$ was only partially impaired by $\mathrm{Zn}$. Such behaviors were probably dependent on $\mathrm{Cd}$-xylem loading mechanisms, as suggested by: i) the analysis of $\mathrm{Zn}$ and $\mathrm{Cd}$ content in the xylem sap performed in relation to the concentration of the two metals in the mobile fractions of the roots; ii) the analysis of the systemic movement of ${ }^{107} \mathrm{Cd}$ in short term experiments performed using a positron-emitting tracer imaging system (PETIS).

Conclusions: Our results suggest that at least two pathways may mediate root-to-shoot $\mathrm{Cd}$ translocation in rice. The former could involve OsHMA2 as $\mathrm{Zn}^{2+} / \mathrm{Cd}^{2+}$ xylem loader, whereas the latter appears to involve a Zn-insensitive system that still needs to be identified.
\end{abstract}

Keywords: Rice, Cadmium, Zinc, Translocation, PETIS

\section{Background}

Cadmium occurs naturally in the environment as a result of volcanic emissions and the weathering of rocks. Anthropogenic activities can contribute to increase the background levels of $\mathrm{Cd}$ in soil, water and living organisms. Important sources of soil contamination are shortor long-range atmospheric depositions from mining

\footnotetext{
*Correspondence: fabio.nocito@unimi.it

${ }^{\dagger}$ Equal contributors

'Dipartimento di Scienze Agrarie e Ambientali - Produzione, Territorio, Agroenergia (DISAA), Università degli Studi di Milano, 20133 Milan, Italy Full list of author information is available at the end of the article
}

activities, phosphate fertilizers and manures, municipal sewage wastes, urban composts and industrial sludges (Alloway and Steinnes 1999; McLaughlin et al. 1999).

Plant-derived foods are the major source of $\mathrm{Cd}$ exposure for humans (EFSA 2009). Although Cd is not essential for plant nutrition, it can be easily taken up from the soil by plant roots and accumulated in different plant organs. In this way, $\mathrm{Cd}$ contamination of soils can result in moderate $\mathrm{Cd}$ accumulation in the edible parts of staple crops, which, in turn, represent the major pathway for $\mathrm{Cd}$ entry into the agricultural food chain, as well as the 
major route for chronic $\mathrm{Cd}$ exposure in general populations (Wagner 1993; FAO/WHO 2001). In humans, Cd is known to accumulate in the kidneys and shows a long biological half-life in the whole body, ranging from 10 to 33 years (Ellis et al. 1979).

Among cereals, rice (Oryza sativa L.) has a genetic propensity to accumulate high level of $\mathrm{Cd}$ in grains (Arao and Ae 2003), sometimes reaching values exceeding the limit of $0.4 \mathrm{mg} \mathrm{kg}^{-1}$ established by the Codex Alimentarius Commission of FAO/WHO (CODEX STAN 193-1995 2015). Interestingly, earlier investigations reported finding that rice-eating ethnic groups such as the people from Japan, Thailand, Hong Kong and Taiwan, have the highest renal $\mathrm{Cd}$ levels in the world (Perry et al. 1961) and that long-term consumption of rice grown in $\mathrm{Cd}$-contaminated paddy soils can cause a high prevalence of renal proximal tubular dysfunction (Kobayashi 1978; Cai et al. 1990; Kobayashi et al. 2002).

Since rice is the staple crop of more than half of the world's population, most of the $\mathrm{Cd}$ exposure through food is likely to come from the consumption of this cereal (Clemens et al. 2013a). For this reason, several efforts have been made to develop a number of agronomic techniques aimed at minimizing the absorption of $\mathrm{Cd}$ by rice (Murakami et al. 2007; Makino et al. 2008; Arao et al. 2010) as well as to understand both the biological bases and the genetic variation of $\mathrm{Cd}$ accumulation in rice grains, with the special aim of developing new low-Cd varieties (Clemens et al. 2013a; Uraguchi and Fujiwara 2013). This last approach seems to be particularly promising since the existence of a high variability for the trait " $\mathrm{Cd}$ accumulation in grain" represents a good starting point for the new challenges of plant breeding (Arao and Ae 2003; Grant et al. 2008; Shi et al. 2009; Uraguchi et al. 2009).

Several processes have been described as involved in $\mathrm{Cd}$ accumulation in rice grains. Briefly, $\mathrm{Cd}$ is absorbed by roots via transport pathways normally involved in the acquisition of mineral nutrients. OsNramp5 (natural resistance-associated macrophage protein 5) - a Mn transporter - has recently been described as the major Cd uptake system in rice (Ishikawa et al. 2012; Sasaki et al. 2012), although $\mathrm{Zn}$ and Fe transporters with limited specificity - such as OsZip1 (Zrt/Irt-like protein 1), OsIRT1 and OsIRT2 (iron regulated transporter 1 and 2), and OsNramp1 - may be implicated in Cd uptake under Zn or Fe deficiency (Ramesh et al. 2003; Nakanishi et al. 2006; Takahashi et al. 2011). Once inside root cells, Cd is translocated to the shoot through the xylem, and then accumulated in leaves and stems. Finally, during the reproductive stage phloem transport seems to be the main process mediating $\mathrm{Cd}$ accumulation in the grains (Tanaka et al. 2007; Kato et al. 2010). During this phase $\mathrm{Cd}$ remobilization from leaves as well as xylem-to-phloem $\mathrm{Cd}$ transfer in the nodes are thought to be essential to determine the final level of Cd into the grains (Rodda et al. 2011; Fujimaki et al. 2010; Uraguchi et al. 2011; Yamaguchi et al. 2012; Kobayashi et al. 2013). Among all these processes xylemmediated root-to-shoot translocation rather than root uptake has been suggested as the main and most common physiological factor accounting for the genotypic variation observed in $\mathrm{Cd}$ accumulation in shoots and grains of rice plants (Uraguchi et al. 2009; Ishikawa et al. 2011). Translocation, in turn, mainly results from the equilibrium between the capability of each rice genotype to retain $\mathrm{Cd}$ in the root and the activities involved in xylem loading (Ueno et al. 2010; Miyadate et al. 2011; Nocito et al. 2011). In this equilibrium, a complex root firewall system - involving the vacuolar sequestration of free $\mathrm{Cd}$ ions (Ueno et al. 2010; Miyadate et al. 2011) or Cd-phytochelatin complexes (Nocito et al. 2011) - traps the excess of Cd within the root, determining, in this way, the total amount of $\mathrm{Cd}$ ions potentially available to be translocated via the xylem in a root-to-shoot direction.

Translocation of $\mathrm{Cd}$ ions to the shoots requires active loading into the xylem (Colangelo and Guerinot 2006). Several experimental sources of evidence indicate OsHMA2 a putative $\mathrm{Zn}$ transporter belonging to the $\mathrm{P}_{1 \mathrm{~B}}$-type ATPase family - as the main candidate protein that could be involved in mediating $\mathrm{Cd}$ - and $\mathrm{Zn}$-xylem loading in rice (Nocito et al. 2011; Satoh-Nagasawa et al. 2012; Takahashi et al. 2012). On the other hand, Yamaji et al. (2013) proposed OsHMA2 as an influx transporter for both $\mathrm{Cd}$ and $\mathrm{Zn}$, involved in the preferential distribution of the two metal ions through the phloem to the developing tissues.

OsHMA2-defective mutants showed a lower translocation ratio for both $\mathrm{Zn}$ and $\mathrm{Cd}$ and reduced $\mathrm{Cd}$ accumulation into the grains as compared to the wild types (Satoh-Nagasawa et al. 2012; Takahashi et al. 2012). Moreover, a careful analysis of mutant phenotypes clearly reveals that root-to-shoot $\mathrm{Cd}$ translocation in rice could be a more complex process than previously thought, since that the lack of OsHMA2 activity had more and stronger effects on $\mathrm{Zn}$ than on $\mathrm{Cd}$ translocation, which indeed was not completely impaired by the mutation (Satoh-Nagasawa et al. 2012). Such a behavior suggests the hypothesis that $\mathrm{Cd}$ and $\mathrm{Zn}$ may only partially share the same pathways for translocation from root to shoot, underlining at the same time important implication for food safety, especially in the cases where the strategies used for containing $\mathrm{Cd}$ accumulation in crops are founded on $\mathrm{Zn}$ fertilization (Oliver et al. 1994; Fahad et al. 2015). Considering these aspects, in this paper we present and discuss a set of competition experiments with $\mathrm{Zn}$ and $\mathrm{Cd}$ which aimed at analyzing their possible interactions and reciprocal effects at the rootto-shoot translocation level. 


\section{Results}

To better characterize the possible interactions between $\mathrm{Zn}$ and $\mathrm{Cd}$ translocation pathways we performed two set of experiments. In the first, rice plants were hydroponically grown and exposed for a 10-day period to a range of three increasing Zn external concentrations (0.1, 1, and $10 \mu \mathrm{M})$ in the absence or presence of a steady amount of $\mathrm{Cd}(0.1 \mu \mathrm{M})$; in the second, plants were exposed for 10 days to different $\mathrm{Cd}$ concentrations $(0,0.01,0.1$, and $1 \mu \mathrm{M})$ in the presence of a steady amount of $\mathrm{Zn}(1 \mu \mathrm{M})$. In all the experiments, changes in metal concentrations did not produce either significant effects on the growth of both roots and shoots, or any apparent symptoms of stress (data not shown): at the end of the exposure period, root and shoot dry weights of a single plant were $0.128 \pm 0.004 \mathrm{~g}$ and $0.588 \pm 0.023 \mathrm{~g}$, respectively.

\section{$\mathrm{Cd}$ and $\mathrm{Zn}$ Partitioning Between Root and Shoot}

Results of the first experiment indicated that, in the absence of any source of $\mathrm{Cd}, \mathrm{Zn}$ concentration in roots and shoots significantly increased as $\mathrm{Zn}$ availability in the external medium did. A similar trend was observed in the presence of a steady amount of $\mathrm{Cd}(0.1 \mu \mathrm{M})$; however, in this condition, $\mathrm{Zn}$ concentration in the shoots was lowered by the presence of $\mathrm{Cd}$, whilst in the roots it was not significantly affected by the presence of the interfering metal (Fig. 1a and b). Finally, Cd accumulation in shoots and roots was significantly affected changing the external $\mathrm{Zn}$ concentration from 0.1 to $1 \mu \mathrm{M}$. Interestingly, a further increase in $\mathrm{Zn}$ availability in the medium - up to $10 \mu \mathrm{M}$ - did not produced any additional decrease in $\mathrm{Cd}$ accumulation (Fig. $1 \mathrm{c}$ and $\mathrm{d}$ ).

In the second experiment, the concentration of $\mathrm{Zn}$ in the shoots significantly decreased as $\mathrm{Cd}$ availability in the external medium increased, whilst $\mathrm{Zn}$ accumulation in the roots did not seem significantly affected by $\mathrm{Cd}$ availability (Fig. 1e and f). Under the same conditions, a dramatic increase in $\mathrm{Cd}$ accumulation was observed in both shoots and roots by changing the external $\mathrm{Cd}$ concentration from 0.01 to $1 \mu \mathrm{M}$ (Fig. $1 \mathrm{~g}$ and $\mathrm{h}$ ).

\section{Analysis of Root-to-Shoot Translocation of $\mathrm{Zn}$ and $\mathrm{Cd}$}

Dynamics of root-to-shoot translocation of $\mathrm{Zn}$ and $\mathrm{Cd}$ were examined by measuring their concentrations in the xylem sap of rice plants exposed to the different combinations of the metals. In these experiments, translocation was estimated as the amount of $\mathrm{Zn}$ or $\mathrm{Cd}$ ions loaded and transported in the xylem sap for $45 \mathrm{~min}$.

The amount of $\mathrm{Zn}$ loaded in the xylem sap linearly increased as $\mathrm{Zn}$ concentration in the external medium did, both in the absence and in the presence of $0.1 \mu \mathrm{M} \mathrm{Cd}^{2+}$ (Fig. 2a). The presence of a steady amount of $\mathrm{Cd}$ $(0.1 \mu \mathrm{M})$ slightly decreased $\mathrm{Zn}$ xylem loading in all the conditions analyzed (Fig. 2a). In the same experiment,
Cd xylem loading was significantly inhibited by changing the external $\mathrm{Zn}$ concentration from 0.1 to $1 \mu \mathrm{M}$, and then was not affected by a further increase in $\mathrm{Zn}$ availability (Fig. 2b). On the other hand, increases in Cd concentration in the external medium progressively reduced Zn xylem loading (Fig. 2c) and resulted in significant increases in the amount of $\mathrm{Cd}$ ions loaded in the xylem sap (Fig. 2d). In the latter case, the $\mathrm{Cd}$ xylem loading curve started to approach saturation at $0.1 \mu \mathrm{M}$.

In both the experimental setups, the ability to load $\mathrm{Zn}$ and $\mathrm{Cd}$ into the xylem was linearly related to the total amount of $\mathrm{Zn}$ and $\mathrm{Cd}$ ions accumulated in the shoots over the 10-day period (Additional file 1: Figure S1).

\section{Effect of $\mathrm{Zn}$ and $\mathrm{Cd}$ Exposure on Thiol Biosynthesis}

Since activation of thiol metabolism may potentially allow a greater proportion of $\mathrm{Zn}$ and $\mathrm{Cd}$ to be retained in roots through vacuolar sequestration, we measured the levels of non-protein thiols (NPTs) in the roots of plants exposed to the different combinations of the two metals. The NPT levels of the roots increased as the $\mathrm{Zn}$ concentration in the external medium did, either in the absence or in the presence of $0.1 \mu \mathrm{M} \mathrm{Cd}^{2+}$. Interestingly, the levels of NPTs measured for each Zn exposure condition significantly increased with the concomitant presence of Cd in the media (Fig. 3a). Finally, the NPT levels in the roots significantly increased as the external $\mathrm{Cd}$ concentration did (Fig. 3b).

\section{Fractioning of $\mathrm{Zn}$ and $\mathrm{Cd}$ in Rice Roots}

Fractioning of $\mathrm{Zn}$ and $\mathrm{Cd}$ retained by roots was carried out using a sequential extraction procedure with buffer and acid (Rauser and Meuwly 1995; Nocito et al. 2011). Additional file 1: Tables S1 and S2 summarize results obtained in representative experiments where the sum of $\mathrm{Zn}$ and/or $\mathrm{Cd}$ ions recovered in the different fractions accounts for at least $97 \%$ of the total $\mathrm{Zn}$ and/or Cd content of the roots. Following extraction, three main metal-ion fractions were obtained: i) buffer soluble (extracts 1-6); ii) acid soluble (extracts 7-9); iii) ash (non-soluble $\mathrm{Zn}$ and/or Cd). Extracts 1 to 6 were further resolved into two fractions, named anionic and cationic, by anion-exchange chromatography (Additional file 1: Figure S2).

The procedure which we used for metal ion fractioning allowed us to discriminate $\mathrm{Zn}$ and $\mathrm{Cd}$ ions: i) retained in complexes with thiol-peptides or other soluble molecules negatively charged in the extraction buffer (anionic fraction); ii) in free cytosolic form and/or bound with ligands (i.e. organic acid and nicotianamine) to form cellular complexes of relatively low thermodynamic stability (cationic fraction); iii) tightly adsorbed to cellular matrices or apoplast components (acid soluble and ash). So, only $\mathrm{Zn}$ and $\mathrm{Cd}$ ions in the cationic 


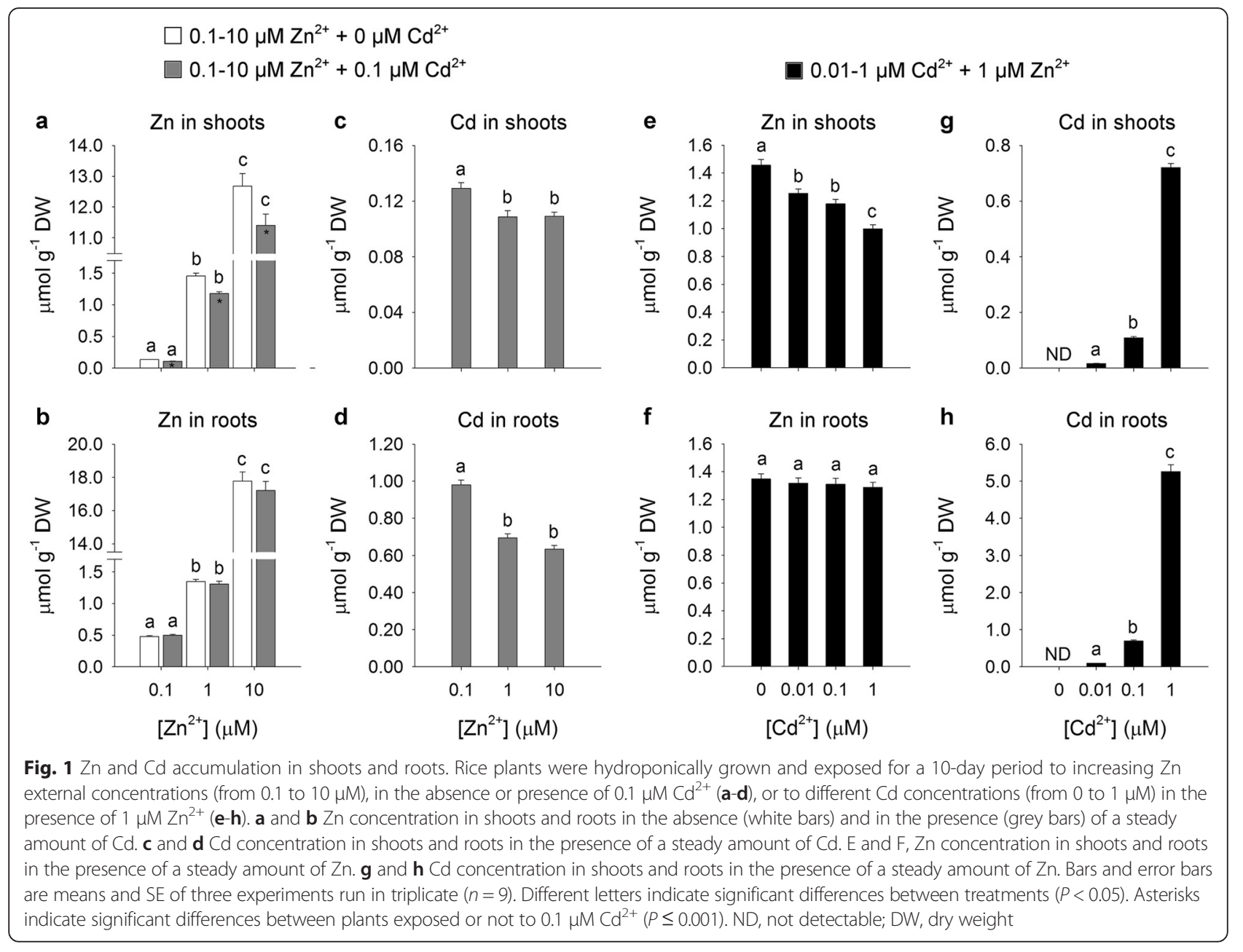

fraction should be considered available for root-to-shoot translocation (Nocito et al. 2011).

An integrated analysis of data in which the total amount of each metal ion retained by roots is divided into two fractions - named mobile (cationic, i.e. potentially available for root-to-shoot translocation) and nonmobile (anionic + acid soluble + ash) - according to Nocito et al. (2011) is reported in Table 1. Results indicated that both mobile and non-mobile fractions of $\mathrm{Zn}$ were linearly related to the $\mathrm{Zn}$ concentration in the external medium, either in the absence or in the presence of $\mathrm{Cd}$; however, the presence of a steady amount of $\mathrm{Cd}$ in the medium significantly enhanced the concentration of $\mathrm{Zn}$ ions in the mobile fractions because of the lowering in the amount of the metal in the non-mobile fractions. In these last conditions, increasing the $\mathrm{Zn}$ external concentration led to decreased $\mathrm{Cd}$ content in the roots (Additional file 1: Tables S2) but did not produce any significant effect on the amount of $\mathrm{Cd}$ in the mobile fraction (Table 1). On the other hand, increasing the $\mathrm{Cd}$ external concentration significantly increased the amount of $\mathrm{Zn}$ and $\mathrm{Cd}$ ions measured in the mobile fractions (Table 1).
Finally, the anionic buffer-soluble fractions were further resolved by gel filtration on a Sephadex G-50 column into peaks I, II and III (Additional file 1: Figure S3). $\mathrm{Zn} / \mathrm{Cd}$ ions into peak I at the void volume of the column $\left(V_{0}\right)$ were ascribed to non-specific adsorption of the metal ions to proteins. Peaks II and III - centered between $V_{o}$ and $V_{t}$ of the column - were designated as the classical high-molecular-weight (HMW) thiol based Cd-binding complexes and low-molecular-weight (LMW) thiol based $\mathrm{Zn}$ - and/or Cd-binding complexes, respectively, since the amount of NPTs recovered in these fractions accounted for $22\left(1 \mu \mathrm{M} \mathrm{Zn}{ }^{2+}, 0 \mu \mathrm{M} \mathrm{Cd}^{2+}\right)$ to $89 \%\left(1 \mu \mathrm{M} \mathrm{Zn}^{2+}, 1 \mu \mathrm{M} \mathrm{Cd}^{2+}\right)$ of the total GSH equivalents measured in the roots; no thiols were found in peaks II and III of the anionic buffer-soluble fraction obtained from roots of plants grown under $0.1 \mu \mathrm{M} \mathrm{Zn}^{2+}$ in the absence of $\mathrm{Cd}^{2+}$ (data not shown). Neither $\mathrm{Zn}$ nor $\mathrm{Cd}$ ions were found at total volume $\left(V_{t}\right)$ of the column $\left(K_{a v}=1\right)$. Peaks II (HMW) were centered around $K_{a v}=0.44$ for Cd, whilst peaks III (LMW) were centered around $K_{a v}=0.58$ and $K_{a v}=0.62$, for $\mathrm{Zn}$ and $\mathrm{Cd}$, respectively. Data analysis revealed that rice roots sequestered $\mathrm{Zn}$ and $\mathrm{Cd}$ differently. 


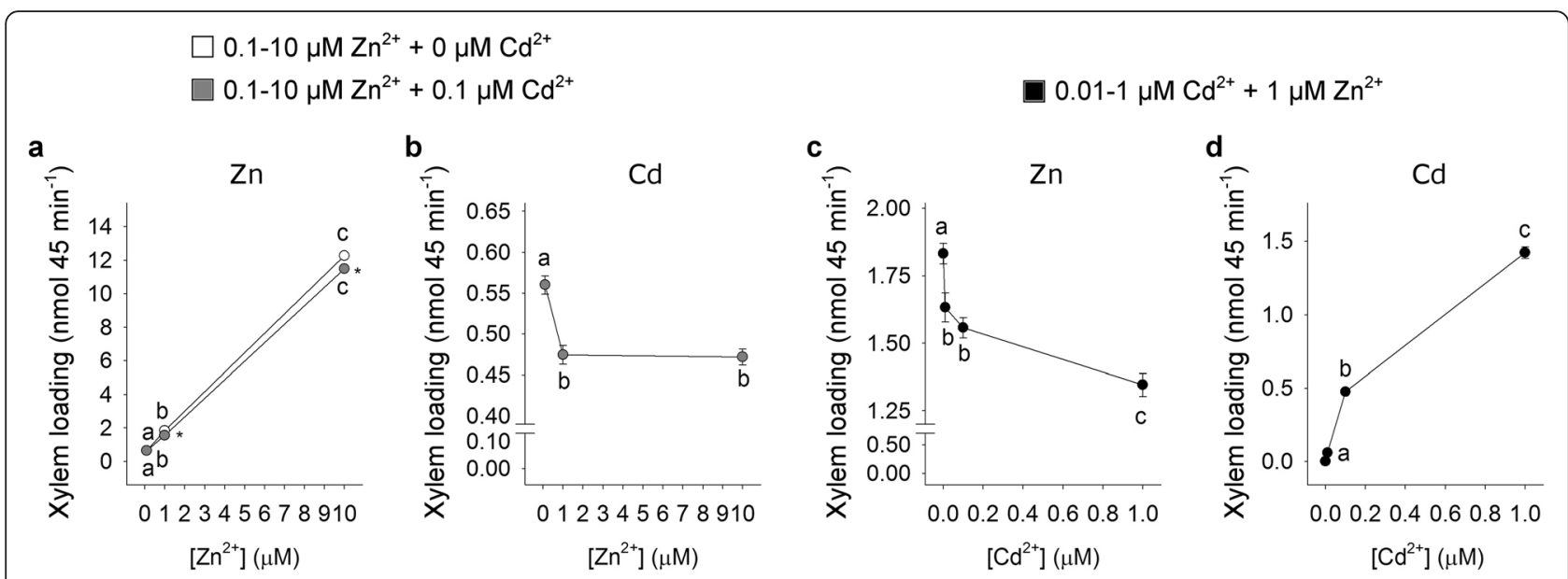

Fig. $2 \mathrm{Zn}$ and $\mathrm{Cd}$ xylem loading. Rice plants were hydroponically grown and exposed for a 10-day period to increasing Zn external concentrations (from 0.1 to $10 \mu \mathrm{M}$ ), in the absence or presence of $0.1 \mu \mathrm{M} \mathrm{Cd}{ }^{2+}(\mathbf{a}$ and $\mathbf{b}$ ), or to different $\mathrm{Cd}$ concentrations (from 0 to $1 \mu \mathrm{M}$ ) in the presence of $1 \mu \mathrm{M}$ $\mathrm{Zn}^{2+}$ (c and $\mathbf{d}$ ). At the end of the exposure period, shoots were separated from roots and the xylem sap exuded from the cut (root side) surface was collected over a 45 min period. a Zn ions loaded and transported in the xylem sap in the absence (white circles) and in the presence (grey circles) of a steady amount of $\mathrm{Cd}$. $\mathbf{b} \mathrm{Cd}$ ions loaded and transported in the xylem sap in the presence of a steady amount of $\mathrm{Cd}$. $\mathbf{c}$ and $\mathbf{d} \mathrm{Zn}$ and $\mathrm{Cd}$ ions loaded and transported in the xylem sap in the presence of a steady amount of Zn. Data are means and SE of three experiments run in triplicate $(n=9)$. Different letters indicate significant differences between treatments $(P<0.05)$. Asterisks indicate significant differences between plants exposed or not to $0.1 \mu \mathrm{MCd}^{2+}(P \leq 0.001)$

In all cases $\mathrm{Zn}$ appeared in LMW complexes. In the absence of any source of Cd, LMW Zn-binding complexes significantly increased as the $\mathrm{Zn}$ external concentration did. Interestingly, the presence of $\mathrm{Cd}$ in the external medium significantly enhanced the amount of $\mathrm{Zn}$ ions found in LMW complexes. Moreover, the amount of $\mathrm{Cd}$ ions in LMW complexes remained constant in all the $\mathrm{Zn}$ conditions analyzed, differently from that found in HMW

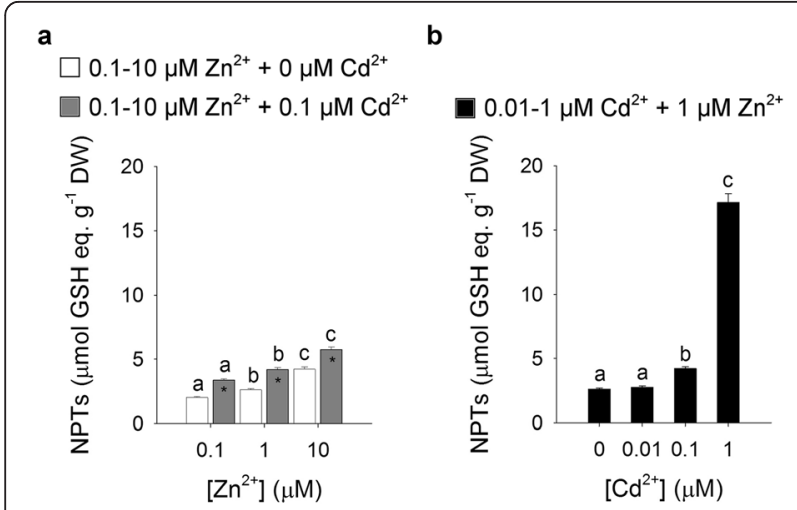

Fig. 3 Total non-protein thiols (NPTs) in the roots. a Rice plants were exposed for a 10-day period to increasing Zn external concentrations (from 0.1 to $10 \mu \mathrm{M}$ ), in the absence (white bars) or presence (grey bars) of $0.1 \mu \mathrm{M} \mathrm{Cd}^{2+}$. b Rice plants were exposed for a 10-day period to different $\mathrm{Cd}$ concentrations (from 0 to $1 \mu \mathrm{M}$ ) in the presence of

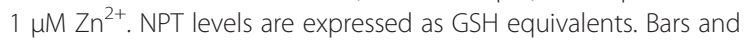
error bars are means and SE of three experiments run in triplicate $(n=9)$. Different letters indicate significant differences between treatments $(P<0.05)$. Asterisks indicate significant differences between plants exposed or not to $0.1 \mu \mathrm{M} \mathrm{Cd}^{2+}(P \leq 0.001)$. DW, dry weight complexes, which instead decreased as Zn external concentration increased. On the other hand, LMW and HMW Cd-binding complexes appeared in a dynamic equilibrium depending on $\mathrm{Cd}$ external concentrations, as indicated by the ratio between the amount of $\mathrm{Cd}$ ions retained in each complex, which notably changed when moving toward the highest $\mathrm{Cd}$ external concentration, in the presence of a steady amount of $\mathrm{Zn}$ (Additional file 1: Tables S3 and S4). Finally, in the same conditions, the amount of $\mathrm{Zn}$ found in LMW complexes significantly increased as Cd external concentration did.

\section{Kinetic Analysis of ${ }^{107} \mathrm{Cd}$ Systemic Movement}

The systemic movement of $\mathrm{Cd}$ in the whole plant was further analyzed using ${ }^{107} \mathrm{Cd}$ in short-term (24 h) PETIS experiments. Figure $4 \mathrm{a}$ shows the field of view of a typical experiment and the regions of interest (ROIs) used to estimate the dynamics of $\mathrm{Cd}$ in the plants. In particular, six ROIs (background, culture solution, distal roots, proximal roots, shoot base, and proximal shoot) were set for each plant. The experiments were started by applying to the roots fresh marked $\left({ }^{107} \mathrm{Cd} ; 0.55 \mathrm{MBq} \mathrm{mL}{ }^{-1}\right)$ culture solutions containing $0.5 \mathrm{mM} \mathrm{CaCl}, 0.1 \mu \mathrm{M} \mathrm{CdCl}$, and different concentrations of $\mathrm{Zn}^{2+}(0.1,1$, and $10 \mu \mathrm{M})$. ${ }^{107} \mathrm{Cd}$ absorption by roots was immediately observed after injection as clearly shown by the comparison of Fig. $4 \mathrm{~b}$ and c. In all the conditions analyzed, the amount of $\mathrm{Cd}$ in the roots increased over time, reaching a common maximum plateau value at about $11 \mathrm{~h}$ both for

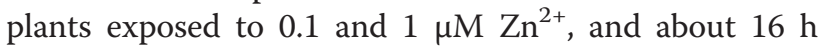
for plants exposed to $10 \mu \mathrm{M} \mathrm{Zn}^{2+}$ (Fig. 4c). Concerning 
Table 1 Partitioning of $\mathrm{Zn}$ and $\mathrm{Cd}$ ions of the roots between potentially mobile and non-mobile fractions

\begin{tabular}{|c|c|c|c|c|c|}
\hline \multicolumn{2}{|c|}{ Metal concentration } & \multicolumn{2}{|l|}{ Mobile fraction } & \multicolumn{2}{|l|}{ Non-mobile fraction } \\
\hline $\mathrm{Zn}$ & $\mathrm{Cd}$ & $\mathrm{Zn}$ & $\mathrm{Cd}$ & $\mathrm{Zn}$ & $\mathrm{Cd}$ \\
\hline$\overline{\mu M}$ & & $n m o l g^{-1} D W$ & & & \\
\hline 0.1 & 0 & $143.03 \pm 3.86(\mathrm{a})$ & ND & $334.78 \pm 11.01$ (a) & ND \\
\hline 1 & 0 & $420.00 \pm 14.70$ (a) & ND & $927.00 \pm 28.54$ (a) & ND \\
\hline 10 & 0 & $3136.82 \pm 128.61(b)$ & ND & $14636.93 \pm 584.18(b)$ & ND \\
\hline 0.1 & 0.1 & $206.02 \pm 6.59$ (a) & $81.66 \pm 2.61(a)$ & $292.83 \pm 10.44$ (a) & $898.72 \pm 32.04(a)$ \\
\hline 1 & 0.1 & $632.25 \pm 22.13(a)$ & $83.00 \pm 2.82(\mathrm{a})$ & $677.22 \pm 26.93(a)$ & $612.57 \pm 20.70(a)$ \\
\hline 10 & 0.1 & $4541.08 \pm 177.10(b)$ & $82.00 \pm 3.53(a)$ & $12669.39 \pm 335.86(b)$ & $552.86 \pm 21.10(b)$ \\
\hline 1 & 0 & $420.00 \pm 14.70$ (a) & ND & $927 \pm 28.54(\mathrm{a})$ & ND \\
\hline 1 & 0.01 & $486.91 \pm 17.04$ (a) & $11.06 \pm 0.32$ (a) & $829.72 \pm 27.26$ (a) & $80.63 \pm 2.76$ (a) \\
\hline 1 & 0.1 & $632.25 \pm 22.13(b)$ & $83.00 \pm 2.82(b)$ & $677.22 \pm 26.93(b)$ & $612.57 \pm 20.70(b)$ \\
\hline 1 & 1 & $696.00 \pm 24.36(b)$ & $349.49 \pm 13.28$ (c) & $591.15 \pm 18.18(b)$ & $4912.21 \pm 137.26(\mathrm{c})$ \\
\hline
\end{tabular}

Rice plants were hydroponically grown and exposed for a 10-day period to increasing Zn external concentrations (from 0.1 to $10 \mu \mathrm{M}$ ), in the absence or presence of $0.1 \mu \mathrm{M} \mathrm{Cd}^{2+}$, or to different $\mathrm{Cd}$ concentrations (from 0 to $1 \mu \mathrm{M}$ ) in the presence of $1 \mu \mathrm{M} \mathrm{Zn^{2+ }}$. Mobile (cationic) and non-mobile (anionic + acid soluble + ash) metal ion fractions are derived using data reported in Additional file 1: Table S1 and S2. Data are means and SE of three experiments, each performed with eight plants $(n=3)$. Different letters indicate significant differences between treatments $(P<0.05)$. ND, not detectable; DW, dry weight

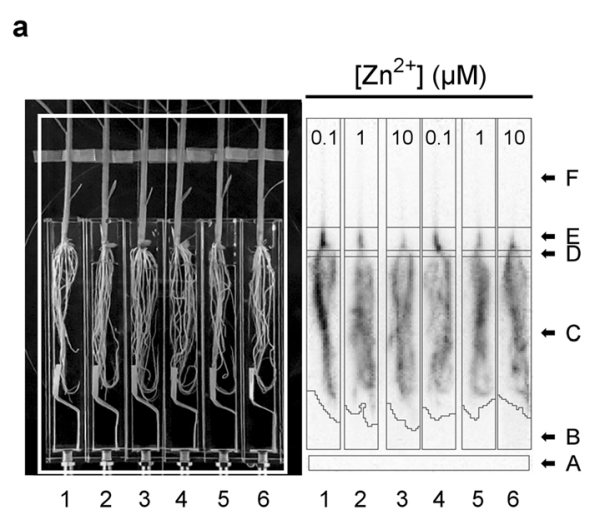

C

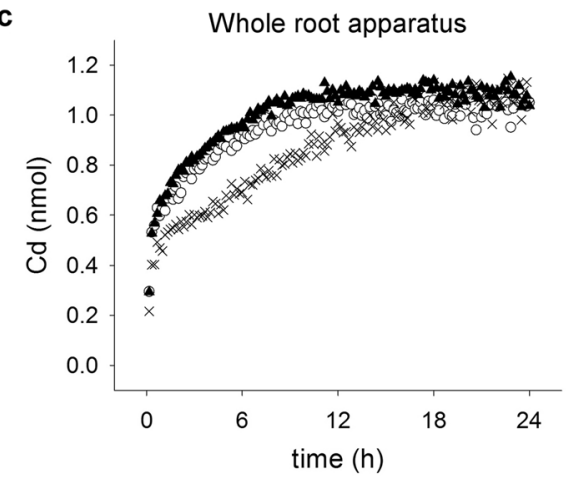

b

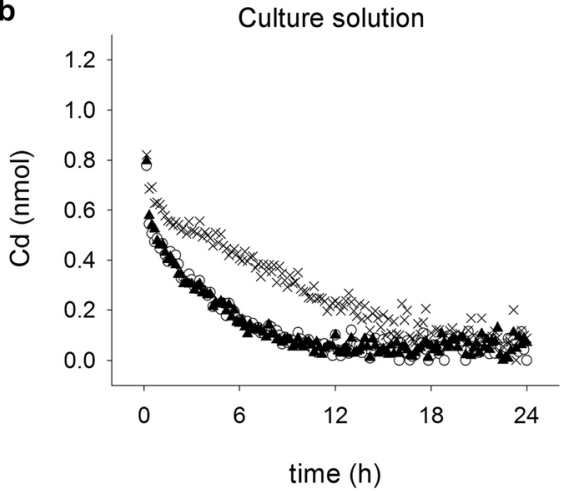

d

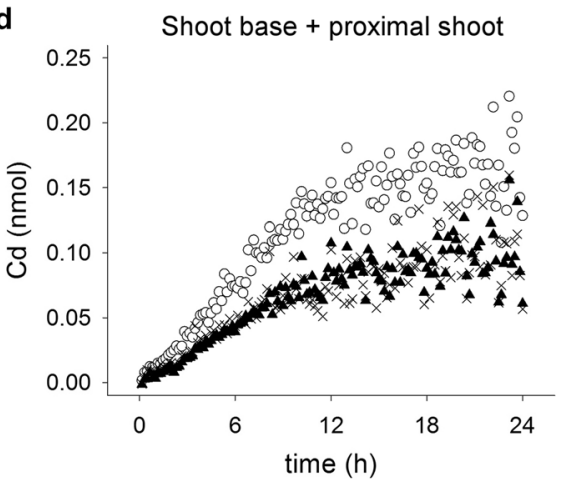

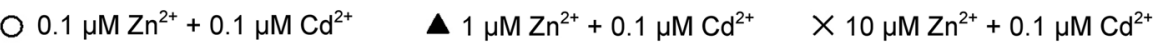

Fig. 4 Time-course analysis of $\mathrm{Cd}$ systemic movement. Rice plants were exposed for a $24-\mathrm{h}$ period to different $\mathrm{Zn}$ concentrations (from 0.1 to $10 \mu \mathrm{M}$ ), in the presence of $0.1 \mu \mathrm{M} \mathrm{Cd}{ }^{2+}$ enriched with ${ }^{107} \mathrm{Cd}$. a Image of rice plants used in a typical PETIS experiment. The field of view of PETIS is bordered by the white continuous line. ROls used for time-course analysis are indicated with arrows in the adjacent panel. ROI-A, background; ROI-B, culture solution; ROI-C, distal root; ROI-D, proximal root; ROI-E, shoot base; ROI-F, proximal shoot. $\mathbf{b}$ and $\mathbf{d}$ Time-course analysis of Cd dynamics in the culture solution (b), whole root apparatus (c), and shoot base + proximal shoot (d). White circles, black triangles, and thin $\times$ refer

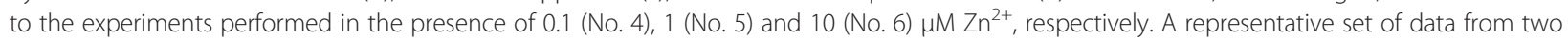
independent experiments performed with two plants for each $\mathrm{Zn}$ exposure condition is given 
the shoots (Fig. 4d), ${ }^{107} \mathrm{Cd}$ signals appeared in the lower parts of the stems (shoot bases; Additional file 1: Figure S4) within $1 \mathrm{~h}$ from the injections and then linearly increased at least up to $10 \mathrm{~h}$. Considering the initial slope of each curve (from 0 to $10 \mathrm{~h}$ ) we estimated that the rate of $\mathrm{Cd}$ translocation was significantly higher in plants exposed to $0.1 \mu \mathrm{M} \mathrm{Zn}{ }^{2+}\left(12.6 \pm 0.3 \mathrm{pmol} \mathrm{h}^{-1}\right)$ compared

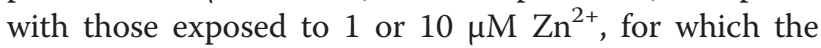
estimated rates of $\mathrm{Cd}$ translocation were similar $(7.8 \pm$ $0.2 \mathrm{pmol} \mathrm{h}^{-1}$ or $7.5 \pm 0.4 \mathrm{pmol} \mathrm{h}^{-1}$, respectively). Similar results were obtained in a second independent analysis (Additional file 1: Figure S5).

\section{Discussion}

The specific interactions between $\mathrm{Zn}$ and $\mathrm{Cd}$ in rice recently reviewed by Chaney (2015) - often appear anomalous if compared to those observed in other staple crops, since the routes used by $\mathrm{Cd}$ to enter root cells seem to be closely dependent on $\mathrm{Zn}$ nutritional status. Honma and Hirata (1978) described a noticeable effect of $\mathrm{Zn}$ starvation on $\mathrm{Cd}$ uptake. On the other hand, under $\mathrm{Zn}$ sufficiency or excess $\mathrm{Cd}$ uptake and accumulation become independent from the levels of $\mathrm{Zn}$ in the soils, in strong contrast with other cereal grains and vegetables (Chaney 2015). The peculiar ability of rice to accumulate soil $\mathrm{Cd}$ and not $\mathrm{Zn}$ in the grains when grown on $\mathrm{Zn} / \mathrm{Cd}$ co-contaminated soils, in which the level of $\mathrm{Zn}$ are up to 100-fold higher than those of $\mathrm{Cd}$, is impressive (Simmons et al. 2003; Chaney 2010). Such a behavior has important implications for human health in subsistence rice consumers, because the level of dietary $\mathrm{Zn}$ are known to influence $\mathrm{Cd}$ absorption in animal tissues (Fox et al. 1984; Fox 1988; McKenna et al. 1992; Reeves and Chaney 2004). It is now clear that the biological bases of these anomalies are likely due to the presence of multiple transport systems able to mediate Cd uptake (see also the introduction section), whose prevalence, ion specificity and regulation may strongly affect the interaction between $\mathrm{Zn}$ and $\mathrm{Cd}$ at different levels. Such a relative complexity may make it difficult to study the relationship existing between $\mathrm{Zn}$ and $\mathrm{Cd}$ at the root-to-shoot translocation level, since possible competitions could be prevented or masked by the relative expression of the transport systems involved in $\mathrm{Zn}$ and/ or Cd uptake at the root level.

To try to clarify these aspects, we performed a complete set of competition experiments with $\mathrm{Zn}$ and $\mathrm{Cd}$ using rice plants grown in a soil-free system, aimed at obtaining a wide range of $\mathrm{Zn}$ and $\mathrm{Cd}$ concentrations at the root level. To these purposes we chose to grow plants under a non-saturating range of $\mathrm{Zn}$ external concentrations, in order to allow variable amounts of $\mathrm{Cd}$ to be absorbed at least through two main transport systems with different selectivity: i) OsZip1 (i.e. a Zn transporter up-regulated under $\mathrm{Zn}$ deficiency and able to move both $\mathrm{Zn}$ and Cd; Ramesh et al. 2003); ii) OsNramp5 (i.e. a Mn transporter able to move Cd, but not $\mathrm{Zn}$; Sasaki et al. 2012). In our experimental conditions the final $\mathrm{Zn} / \mathrm{Cd}$ concentration ratio into the roots ranged from $0.24\left(\mathrm{Zn}^{2+}\right.$ $\left.1 \mu \mathrm{M} ; 1 \mu \mathrm{M} \mathrm{Cd}^{2+}\right)$ to $27.11\left(\mathrm{Zn}^{2+} 10 \mu \mathrm{M} ; 0.1 \mu \mathrm{M} \mathrm{Cd}^{2+}\right)$.

The main results we obtained clearly indicate the lack of a full reciprocity when considering the effect of $\mathrm{Cd}$ on $\mathrm{Zn}$ accumulation, and vice versa, since the accumulation of $\mathrm{Zn}$ in the shoots was significantly inhibited by $\mathrm{Cd}$ increases in all the analyzed conditions, whereas that of $\mathrm{Cd}$ was only partially impaired by $\mathrm{Zn}$ increases (Fig. 1). In fact, $\mathrm{Cd}$ accumulation in the shoots was reduced by $16 \%$ by changing the external $\mathrm{Zn}$ concentration by one order of magnitude (from 0.1 to $1 \mu \mathrm{M}$ ), then remained unaffected by a further increase in $\mathrm{Zn}$ availability, from 1 to $10 \mu \mathrm{M}$, indicating that $\mathrm{Cd}$ accumulation in this range was a $\mathrm{Zn}$-independent process. However, from these data we cannot conclude that the effects of $\mathrm{Zn}$ on shoot $\mathrm{Cd}$ accumulation necessarily result from mechanisms involved in root-to-shoot $\mathrm{Cd}$ translocation, since $\mathrm{Cd}$ absorption by plant roots seemed affected by $\mathrm{Zn}$ concentration, as indicated by the total amount of $\mathrm{Cd}$ in the whole plant, whose value decreased as $\mathrm{Zn}$ concentration in the external medium increased (Fig. 1c and d). A similar observation may be done concerning $\mathrm{Zn}$ accumulation in the shoots under different $\mathrm{Cd}$ concentrations (Fig. 1e and f). Such behaviors could be reasonably due to the range of $\mathrm{Zn}$ concentrations we used for the experiments. However, the ability to load $\mathrm{Zn}$ and $\mathrm{Cd}$ into the xylem was linearly related to total amounts of $\mathrm{Zn}$ and $\mathrm{Cd}$ ions accumulated in the shoots over the 10-day period (Fig. 2, Additional file 1: Figure S1). This suggests the hypothesis that the differential effect produced by the two metals on $\mathrm{Zn}$ and $\mathrm{Cd}$ accumulation in the shoot was reasonably due to the existence of at least two translocation pathways with different metal selectivity. It is also important to consider that the total amounts of $\mathrm{Zn}$ and $\mathrm{Cd}$ ions in the root tissues are often poor indicators of their actual availability for loading into the xylem and then being translocated in a root-to-shoot direction, since, once inside the cells, $\mathrm{Zn}$ and $\mathrm{Cd}$ ions may be trapped within the root through selective binding sites or molecules with high affinity for the metals or through transfer across a membrane into an intracellular compartment (Clemens 2006; Ueno et al. 2010; Nocito et al. 2011). Moreover, the selective binding of $\mathrm{Zn}$ with lowmolecular weight ligand, such as nicotianamine (NA), may promote both symplastic movement and longdistance distribution of the metal ion within the plant (Lee et al. 2011; Deinlein et al. 2012; Haydon et al. 2012). Thus, the concentration of $\mathrm{Zn}$ and $\mathrm{Cd}$ ions potentially mobile in the plants results from several different biochemical and physiological processes involved in metal 
chelation, compartmentalization and adsorption (Souza and Rauser 2003; Nocito et al. 2011; Sinclair and Krämer 2012; Clemens et al. 2013b; Olsen and Palmgren 2014).

It has been shown that different photosynthetic organisms respond to excess of $\mathrm{Zn}$ and $\mathrm{Cd}$ ions by producing phytochelatins (PCs), a class of thiol compounds involved in metal chelation and vacuolar sequestration (Grill et al. 1987; Grill et al. 1988; Zenk 1996; Tennstedt et al. 2009; García-García et al. 2014; Song et al. 2014), which may largely contribute to $\mathrm{Zn}$ and $\mathrm{Cd}$ retention within the root (Tennstedt et al. 2009; Wong and Cobbett 2009). In our conditions, rising $\mathrm{Zn}$ or Cd exposure progressively increased, with different efficiency, the level of NPTs in the roots (Fig. 3). Such a finding may be reasonably ascribable to the activation of PC biosynthesis, as revealed by the gel filtration analysis of the anionic fractions in which most of the $\mathrm{Zn}$ and $\mathrm{Cd}$ ions were immobilized with thiol compounds in LMW and HMW complexes (Additional file 1: Figure S3, Tables S3 and S4), as previously reported in other papers (Rauser and Meuwly 1995; Souza and Rauser 2003; Nocito et al. 2011). Moreover, fractioning of metals accumulated in the root also revealed that the three main fractions were in a dynamic equilibrium in which the increases in $\mathrm{Zn}$ or Cd external concentration, in the presence of a steady amount of $\mathrm{Cd}$ or $\mathrm{Zn}$, respectively, resulted in changes in the amounts of the two metal ions in each fraction (Additional file 1: Tables S1 and S2).

Focusing the attention on the cationic fractions (Table 1, Additional file 1: Tables S1 and S2) we can make some educated guesses about changes in the relative mobility of $\mathrm{Zn}$ and $\mathrm{Cd}$ into the root, since, as discussed above, only the metal ions belonging to these fractions have all the requisites to be considered potentially mobile and then available for root-to-shoot translocation (Nocito et al. 2011; Additional file 1: Figure S2). In fact, the fraction of buffer-soluble $\mathrm{Zn}$ and $\mathrm{Cd}$ not immobilized by the anion exchanger may have come from $\mathrm{Zn}$ and $\mathrm{Cd}$ ions in free cytosolic form or bound with organic acids or NA to form cellular complexes of relatively high mobility inside the plant (Krotz et al. 1989; Deinlein et al. 2012).

Increases in $\mathrm{Zn}$ external concentration, in the presence of a steady amount of $\mathrm{Cd}$, did not produced significant changes in the amount of $\mathrm{Cd}$ ions in the mobile fractions but conversely enhanced the amount of free $\mathrm{Zn}$ ions in the same fractions. Such behaviors may be ascribable to competition phenomena between the two ions for both root absorption and negative charges on cellular matrices or apoplast components. In fact, the increases in $\mathrm{Zn}$ external concentration not only resulted in a reduced total amount of $\mathrm{Cd}$ in the roots, but also displaced non-mobile $\mathrm{Cd}$ ions from cellular matrices (Table 1, Additional file 1: Tables S1 and S2). On the other hand, the increases in $\mathrm{Cd}$ external concentration, in the presence of a steady amount of $\mathrm{Zn}$, significantly enhanced the amount of both $\mathrm{Zn}$ and $\mathrm{Cd}$ ions in the mobile fractions (Table 1, Additional file 1: Tables S1 and S2). Also in this case, we can speculate that the gradual saturation of cellular matrices with $\mathrm{Cd}$ ions may have displaced $\mathrm{Zn}$ ions leading to a transient increase in the activity of the free $\mathrm{Zn}$ forms that, in turn, was only partially counterbalanced by a weak increase in the amount of $\mathrm{Zn}$ ions immobilized with thiol compounds in the LMW complexes (Additional file 1: Figure S3, Tables S3 and S4). Finally, by plotting the xylem loading data obtained in the two experimental setups as a function of the $\mathrm{Zn} / \mathrm{Cd}$ or $\mathrm{Cd} / \mathrm{Zn}$ concentration ratios in the mobile fractions, we can easily deduce that increases in the $\mathrm{Zn} / \mathrm{Cd}$ ratio did not produce fully reciprocal effects on $\mathrm{Zn}$ and $\mathrm{Cd}$ translocation, whilst increases in the $\mathrm{Cd} /$ $\mathrm{Zn}$ ratio resulted in fully reciprocal effects (Fig. 5). Such a finding strongly confirms the hypothesis that $\mathrm{Cd}$ ions may use at least two distinct pathways to be translocated from roots to shoots. The first one - shared with $\mathrm{Zn}-$ is probably used for $\mathrm{Zn}$ translocation in physiological conditions, whilst the second one appears as a $\mathrm{Zn}$ insensitive route that $\mathrm{Cd}$ may preferentially use when the first pathway is saturated with $\mathrm{Zn}$. Moreover, the $\mathrm{Zn}$-insensitive pathway we postulate seems to be independent from $\mathrm{Cd}$ stress or nutritional status reached by plants under $\mathrm{Zn}$ excess $(10 \mu \mathrm{M})$, since the partial inhibitory effect exerted by $\mathrm{Zn}$ on $\mathrm{Cd}$ translocation was also observed in short-term PETIS experiments performed with unstressed rice plants (Fig. 4). In fact, time-course analysis of $\mathrm{Cd}$ systemic movement in the plants revealed that: i) the rate of $\mathrm{Cd}$ translocation was significantly reduced by changing the external concentration of $\mathrm{Zn}$ from 0.1 to $1 \mu \mathrm{M}$ and then remained unaffected following a further increase in $\mathrm{Zn}$ availability (Fig. 4d); ii) the rates of $\mathrm{Cd}$ translocation measured in the presence of different $\mathrm{Zn}$ external concentrations significantly differed just starting from the first hour of exposure (Fig. 4d), suggesting that the hypothetical $\mathrm{Zn}$-insensitive pathway was constitutively expressed and not induced by changes in the nutritional status of the rice plants. It is also noteworthy that rates of $\mathrm{Cd}$ translocation measured in the presence of 1 and $10 \mu \mathrm{M} \mathrm{Zn}{ }^{2+}$ did not significantly differ even if the highest $\mathrm{Zn}$ concentration we tested strongly reduced the rate of $\mathrm{Cd}$ accumulation in the roots (Fig. 4). Such a finding clearly confirms that the gradual saturation of the $\mathrm{Zn}$-dependent pathway with $\mathrm{Zn}$ may force $\mathrm{Cd}$ ions to move through the second pathway, suggesting that the two translocation routes normally compete for free $\mathrm{Cd}$ ions into the root. Moreover, our main conclusion seems to be further supported by the paper of SatohNagasawa et al. (2012) which showed that rice mutants defective for OsHMA2 - the main candidate transport system so far described in rice as involved in xylem- 


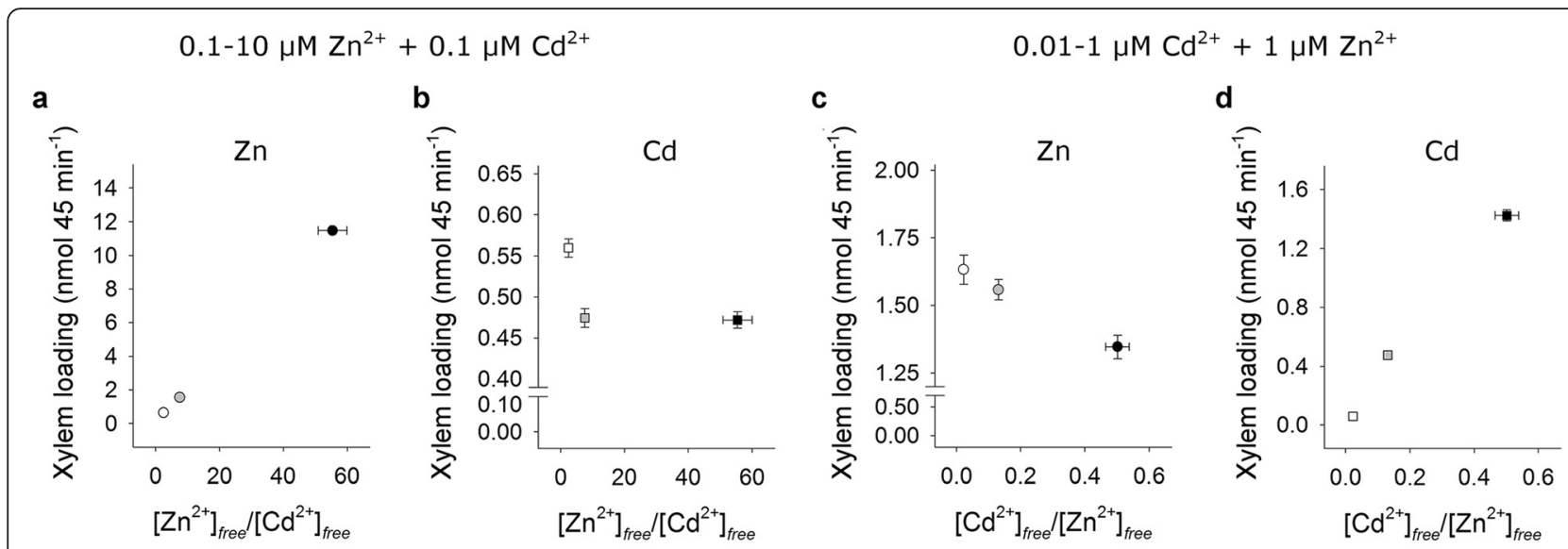

Fig. 5 Analysis of metal xylem loading as a function of $\mathrm{Zn}$ and $\mathrm{Cd}$ concentration in the mobile fractions. Rice plants were hydroponically grown and exposed for a 10-day period to increasing Zn external concentrations (from 0.1 to $10 \mu \mathrm{M}$ ), in the presence of $0.1 \mu \mathrm{M} \mathrm{Cd}{ }^{2+}(\mathbf{a}$ and $\mathbf{b}$ ), or to different $\mathrm{Cd}$ concentrations (from 0.01 to $1 \mu \mathrm{M}$ ) in the presence of $1 \mu \mathrm{M} \mathrm{Zn^{2+ }}$ (c and $\mathbf{d}$ ). $\mathbf{a}$ and $\mathbf{b} \mathrm{Zn}$ (circles) and Cd (square) translocation in

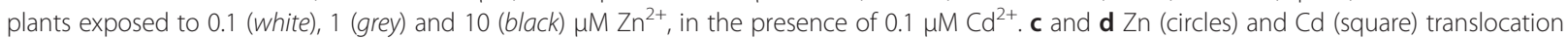

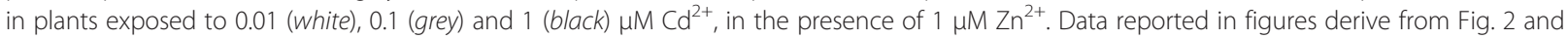
Additional file 1: Tables S1 and S2

mediated $\mathrm{Zn}^{2+} / \mathrm{Cd}^{2+}$ translocation (Nocito et al. 2011; Satoh-Nagasawa et al. 2012; Takahashi et al. 2012; SatohNagasawa et al. 2013; Yamaji et al. 2013) - had a residual capacity to translocate $\mathrm{Cd}$ to the shoots. Finally, the fact that wild-type plants - rather than mutants or genetically manipulated plants - were used in the present study strengthens the notion that long-distance transport of $\mathrm{Cd}$ along alternative pathways is a physiological process that generally occurs under $\mathrm{Zn}$ excess and does not result from anomalous or compensatory expression of other nonselective transporters.

\section{Conclusions}

Our data provide several forms of evidence to support the hypothesis that at least two distinct and competing pathways may take part in mediating root-to-shoot $\mathrm{Cd}$ translocation in rice. The first one, prevailing at relatively low $\mathrm{Zn}$ concentrations, could involve OsHMA2 as the $\mathrm{Zn}^{2+} / \mathrm{Cd}^{2+}$ xylem loading system, while the second one appears to involve a $\mathrm{Zn}$-insensitive system that still needs to be identified among transporters showing $\mathrm{Cd}$ efflux activity in the vascular tissues of the roots.

\section{Methods}

\section{Plant Material, Growth Conditions and Sampling}

Rice (O. sativa L. cv. Roma) caryopses were placed on filter paper saturated with distilled water and incubated in the dark at $26{ }^{\circ} \mathrm{C}$. Seven days later, seedlings were transplanted into $5 \mathrm{~L}$ plastic tanks (eight seedlings per tank) containing the following complete nutrient solution (pre-growing solution): $1.5 \mathrm{mM} \mathrm{KNO}_{3}, 1 \mathrm{mM}$ $\mathrm{Ca}\left(\mathrm{NO}_{3}\right)_{2}, 500 \mu \mathrm{M} \mathrm{MgSO}, 250 \mu \mathrm{M} \mathrm{NH}{ }_{4} \mathrm{H}_{2} \mathrm{PO}_{4}, 25 \mu \mathrm{M}$

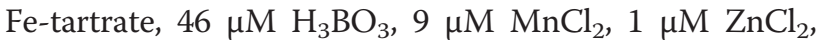

$0.3 \mu \mathrm{M} \mathrm{CuCl} 2,0.1 \mu \mathrm{M}\left(\mathrm{NH}_{4}\right)_{6} \mathrm{Mo}_{7} \mathrm{O}_{24}, 30 \mu \mathrm{M} \mathrm{Na} \mathrm{O}_{3} \mathrm{Si}$ ( $\mathrm{pH}$ 6.5). Seedlings were kept for a 12-day pre-growing period in a growth chamber maintained at $26{ }^{\circ} \mathrm{C}$ and $80 \%$ relative humidity during the $16 \mathrm{~h}$ light period and at $22{ }^{\circ} \mathrm{C}$, and $70 \%$ relative humidity during the $8 \mathrm{~h}$ dark period. Photosynthetic photon flux density was $400 \mu \mathrm{mol} \mathrm{m} \mathrm{m}^{-2} \mathrm{~s}^{-1}$. At the end of the pre-growing period, plants were differentially exposed for a 10-day period to different concentrations of $\mathrm{Zn}(0.1,1$ and $10 \mu \mathrm{M})$, in the absence or presence of a steady amount of Cd $(0.1 \mu \mathrm{M})$, or to different concentrations of $\mathrm{Cd}(0,0.01,0.1$ and $1 \mu \mathrm{M})$, in the presence of a steady amount of $\mathrm{Zn}(1 \mu \mathrm{M})$, by supplementing the pre-growing solution with different amounts of $\mathrm{ZnCl}_{2}$ and/or $\mathrm{CdCl}_{2}$. All hydroponic solutions were renewed daily to minimize nutrient depletion. Plants were harvested and roots were washed for $10 \mathrm{~min}$ in icecold $5 \mathrm{mM} \mathrm{CaCl}_{2}$ solution to displace extracellular $\mathrm{Cd}$ (Rauser 1987), rinsed in distilled water and gently blotted with paper towels. Shoots were separated from roots and the tissues were frozen in liquid $\mathrm{N}_{2}$ and stored at $-80{ }^{\circ} \mathrm{C}$, or analyzed immediately.

For positron-emitting tracer imaging system (PETIS) experiments, rice (O. sativa L. cv. Nipponbare) caryopses were germinated on a plastic mesh floating on distilled water, in the dark at $25{ }^{\circ} \mathrm{C}$. Seven days later, seedlings were pre-grown in a one-quarter-strength Kimura B nutrient solution for 7 days and then grown in a full-strength Kimura B nutrient solution for another 7day period. The Kimura $\mathrm{B}$ nutrition solution contained $0.70 \mathrm{mM}\left(\mathrm{NH}_{4}\right)_{2} \mathrm{SO}_{4}, 0.17 \mathrm{mM} \mathrm{Na} \mathrm{HPO}_{4}, 0.27 \mathrm{mM}$ $\mathrm{K}_{2} \mathrm{SO}_{4}, \quad 0.47 \mathrm{mM} \quad \mathrm{MgSO}_{4} \cdot 7 \mathrm{H}_{2} \mathrm{O}, 0.37 \mathrm{mM} \mathrm{CaCl}$, $11 \mathrm{mg} \mathrm{L}^{-1} \mathrm{FeC}_{6} \mathrm{H}_{5} \mathrm{O}_{7}$ (Fe citrate), $0.16 \mu \mathrm{M} \mathrm{CuSO}$, $0.15 \mu \mathrm{M} \quad \mathrm{ZnSO}_{4} \cdot 7 \mathrm{H}_{2} \mathrm{O}, 0.10 \mu \mathrm{M} \quad \mathrm{Na}_{2} \mathrm{MoO}_{4} \cdot 2 \mathrm{H}_{2} \mathrm{O}$, 
$15 \mu \mathrm{M} \mathrm{H}_{3} \mathrm{BO}_{3}$, and $4.6 \mu \mathrm{M} \mathrm{MnSO} \mathrm{M}_{4} \cdot 4 \mathrm{H}_{2} \mathrm{O}$ (pH 5.5). Plants were kept in a growth chamber maintained at $30{ }^{\circ} \mathrm{C}$ and $65 \%$ relative humidity during the $16 \mathrm{~h}$ light period and at $25{ }^{\circ} \mathrm{C}$ and $65 \%$ relative humidity during the $8 \mathrm{~h}$ dark period. Photosynthetic photon flux density was $400 \mu \mathrm{mol} \mathrm{m}{ }^{-2} \mathrm{~s}^{-1}$.

\section{Determination of $\mathrm{Zn}$ and $\mathrm{Cd}$ in Roots and Shoots}

Samples of $200 \mathrm{mg}$ fresh weight (FW) were mineralized at $120{ }^{\circ} \mathrm{C}$ in $5 \mathrm{~mL} 14.4 \mathrm{M} \mathrm{HNO}_{3}$, clarified with $1.5 \mathrm{~mL}$ $33 \%(\mathrm{w} / \mathrm{v}) \mathrm{H}_{2} \mathrm{O}_{2}$, and finally dried at $80{ }^{\circ} \mathrm{C}$. The mineralized material was dissolved in $5 \mathrm{~mL} 0.1 \mathrm{M} \mathrm{HNO}_{3}$ and filtered on a $0.45 \mu \mathrm{m}$ nylon membrane. $\mathrm{Zn}$ and $\mathrm{Cd}$ content was measured by inductively coupled plasma mass spectrometry (ICP-MS; Bruker Aurora M90 ICP-MS).

\section{Analysis of Root-to-Shoot $\mathrm{Zn}$ and Cd Translocation}

At the end of the exposure period, shoots were cut at $2 \mathrm{~cm}$ above the roots with a microtome blade. Xylem sap exuded from the lower cut surface was collected for $45 \mathrm{~min}$ and stored into $1.5 \mathrm{~mL}$ plastic vials. The amount of collected sap was determined by weighing and the concentration of $\mathrm{Zn}$ and $\mathrm{Cd}$ was measured by ICP-MS.

\section{Determination of Total non-Protein Thiols}

Roots were pulverized using mortar and pestle in liquid $\mathrm{N}_{2}$ and stored frozen in a cryogenic tank. Four hundred milligrams of root powders were extracted in $600 \mu \mathrm{L}$ of $1 \mathrm{M} \mathrm{NaOH}$ and $1 \mathrm{mg} \mathrm{mL}^{-1} \mathrm{NaBH}_{4}$, and the homogenate was centrifuged for $15 \mathrm{~min}$ at $13000 \mathrm{~g}$ and $4{ }^{\circ} \mathrm{C}$. Four hundred microliters of supernatant were collected, $66 \mu \mathrm{L}$ of $37 \% \mathrm{HCl}$ was added and then the mixture was centrifuged again for $10 \mathrm{~min}$ at $13000 \mathrm{~g}$ and $4{ }^{\circ} \mathrm{C}$. For the quantification, volumes of $200 \mu \mathrm{L}$ of the supernatant were collected and mixed with $800 \mu \mathrm{L}$ of $1 \mathrm{M} \mathrm{K}-\mathrm{Pi}$ buffer ( $\mathrm{pH} 7.5)$ containing or not $0.6 \mathrm{mM}$ Ellman's reagent $\left\{\left[5,5^{\prime}\right.\right.$-dithiobis(2-nitrobenzoic acid); DTNB $\left.]\right\}$. The samples' absorbances at $412 \mathrm{~nm}$ were then spectrophotometrically measured.

\section{$\mathrm{Zn}$ and $\mathrm{Cd}$ Fractioning}

Metal fractioning was carried out essentially as described by Rauser and Meuwly (1995). Briefly, frozen root tissues (2 g FW) were pulverized in a cold mortar with a pestle and then homogenized with ice-cold $\mathrm{N}_{2}$-purged $100 \mathrm{mM}$ Tris- $\mathrm{HCl}$ (pH 8.6), $1 \mathrm{mM}$ phenylmethanesulfonyl fluoride (PMSF) and $1 \%(\mathrm{v} / \mathrm{v})$ Tween 20 at the ratio of $1 \mathrm{~mL}$ of buffer to $1 \mathrm{~g}$ tissue FW. The homogenate was centrifuged at $4{ }^{\circ} \mathrm{C}$ and $48000 \mathrm{~g}$ for $6 \mathrm{~min}$, the supernatant (extract 1 ) was collected and frozen immediately in liquid $\mathrm{N}_{2}$, and the pellet was resuspended in a volume of $\mathrm{N}_{2}$-purged $10 \mathrm{mM}$ Tris- $\mathrm{HCl}(\mathrm{pH}$ 8.6) and $1 \%(\mathrm{v} / \mathrm{v})$ Tween 20 , previously used to rinse the mortar kept on ice. The suspension was centrifuged again, and the supernatant (extract 2) was collected and added to the extract 1 for freezing. Resuspension and centrifugation of the homogenized tissue debris was repeated four more times to collect extracts 3-6. At the end of this sequence, the pellet was suspended in a volume of ice-cold $100 \mathrm{mM} \mathrm{HCl}$, centrifuged at $4{ }^{\circ} \mathrm{C}$ and $48000 \mathrm{~g}$ for $6 \mathrm{~min}$ and the supernatant (extract 7) was retained. This sequence was repeated two more times to obtain extracts 8 and 9. The exhausted pellet was transferred to a glass tube, mineralized at $120{ }^{\circ} \mathrm{C}$ in $10 \mathrm{~mL} 14.4 \mathrm{M} \mathrm{HNO}_{3}$, clarified with $3 \mathrm{~mL} 33 \%(\mathrm{w} / \mathrm{v}) \mathrm{H}_{2} \mathrm{O}_{2}$ and finally dried at $80{ }^{\circ} \mathrm{C}$. The mineralized material was dissolved in $5 \mathrm{~mL}$ $0.1 \mathrm{M} \mathrm{HNO}_{3}$ and filtered on a $0.45 \mu \mathrm{m}$ nylon membrane.

Extracts 1 to 6 were resolved into two fractions, referred to as anionic and cationic, by anion-exchange chromatography. Buffer extract was loaded, at $20 \mathrm{~mL} \mathrm{~h}^{-1}$, onto a $0.5 \times 2 \mathrm{~cm}$ column of diethylaminoethyl cellulose (DEAE) Sephadex A-25 (GE Healthcare) equilibrated with $10 \mathrm{mM}$ Tris- $\mathrm{HCl}(\mathrm{pH}$ 8.6). After loading, the column was washed with $50 \mathrm{~mL}$ of equilibrating buffer to remove unadsorbed solutes. All the fluid passing through the anion exchanger was collected for $\mathrm{Zn}$ and $\mathrm{Cd}$ analysis (cationic fraction). Anionic material was eluted with $6 \mathrm{~mL}$ of $10 \mathrm{mM}$ Hepes $(\mathrm{pH}$ 8.0) and $1 \mathrm{M} \mathrm{KCl}$. Five milliliters of the anionic fraction so obtained were further resolved by gel filtration on a Sephadex G-50 (Sigma) column $(0.8 \times 130 \mathrm{~cm})$ equilibrated with $10 \mathrm{mM}$ Hepes (pH 8.0) and $300 \mathrm{mM} \mathrm{KCl}$. The column was developed in equilibrating buffer at $12.5 \mathrm{~mL} \mathrm{~h}^{-1}$ at $4{ }^{\circ} \mathrm{C}$. The absorbance at $254 \mathrm{~nm}$ was recorded and fractions of about $5 \mathrm{~mL}$ were collected for $\mathrm{Zn}, \mathrm{Cd}$, and NPT analysis. The column was calibrated by using $5 \mathrm{~mL}$ of $0.25 \%$ (w/v) blue dextran 2000 and $1 \%(\mathrm{w} / \mathrm{v}) \mathrm{K}_{3} \mathrm{Fe}(\mathrm{CN})_{6}$ to estimate void $\left(V_{0}\right)$ and total volume $\left(V_{\mathrm{t}}\right)$, respectively. The partition coefficient, $K_{\mathrm{av}}$, was calculated using the following equation: $K_{\mathrm{av}}=\left(V_{\mathrm{e}}\right.$ $\left.-V_{0}\right) /\left(V_{\mathrm{t}}-V_{0}\right)$, where $V_{\mathrm{e}}$ was the elution volume. For total non-protein thiol determination, selected fractions from gel filtration were pooled in a glass tube, lyophilized, and finally analyzed as described above. The amount of $\mathrm{Zn}$ and $\mathrm{Cd}$ ions in mineralized pellets, extracts and column effluents was measured by ICP-MS.

\section{${ }^{107} \mathrm{Cd}$ Tracer}

${ }^{107} \mathrm{Cd}$ was produced as described by Fujimaki et al. (2010). Briefly, a silver foil was bombarded for $2 \mathrm{~h}$ with a $17-\mathrm{MeV}$ energetic proton beam, at a current of $5 \mu \mathrm{A}$ from a cyclotron, at Takasaki Ion Accelerators for Advanced Radiation Application, Japan Atomic Energy Agency. The irradiated material was dissolved in $\mathrm{HNO}_{3}$, and then diluted in warm water. Silver was precipitated by adding to the solution a 0 to $2 \mathrm{M}$ gradient of $\mathrm{HCl}$. Supernatant, containing ${ }^{107} \mathrm{Cd}$, was filtered, dried and 
dissolved in water. Aliquots of ${ }^{107} \mathrm{Cd}(6.7 \mathrm{MBq})$ were added to $12.2 \mathrm{~mL}$ of the culture solutions $[0.5 \mathrm{mM}$ $\mathrm{CaCl}_{2}, 0.1 \mu \mathrm{M}$ nonradioactive $\mathrm{CdCl}_{2}$, different concentrations $(0.1,1,10 \mu \mathrm{M})$ of $\mathrm{ZnSO}_{4}$ ] used for each plant in the experiments.

\section{PETIS Imaging}

Rice plants were transferred into appropriate $120 \times 14 \times$ $10 \mathrm{~mm}$ plastic vessels, containing $12 \mathrm{~mL}$ of full-strength Kimura B nutrient solution. Before starting the experiments, plants were acclimatized for $1 \mathrm{~h}$ in aerated $0.5 \mathrm{mM}$ $\mathrm{CaCl}_{2}$ solutions. In a typical experiment, 6 vessels - each containing one plant - were placed in the mid-plane between two opposing detector heads of the PETIS apparatus (a modified type of PPIS-4800; Hamamatsu Photonics, Japan). Detectors were focused on the plants in order to observe the culture solutions, the whole root apparatus, the shoot bases, and the proximal portions of the shoots, in a $12 \times 19 \mathrm{~cm}$ field of view (FOV). The entire setup was installed in a growth chamber maintained at $30{ }^{\circ} \mathrm{C}$ and $65 \%$ relative humidity in continuous light at the density of $400 \mu \mathrm{mol} \mathrm{m}^{-2} \mathrm{~s}^{-1}$.

PETIS experiments were started by injecting the ${ }^{107} \mathrm{Cd}$ marked culture solutions in the different plastic vessels. All the solutions were continuously stirred with gentle aeration in order to maintain a uniform composition. The surface level of the solution in the vessels was maintained by supplying fresh $0.5 \mathrm{mM} \mathrm{CaCl}$ solutions with an appropriate solution supply system. Images of the ${ }^{107} \mathrm{Cd}$ distribution in the FOV were obtained every one minute for $24 \mathrm{~h}$. The data of serial images obtained from the PETIS apparatus were analyzed for ${ }^{107} \mathrm{Cd}$ distribution in specific regions of interest (ROIs; background, culture solution, distal roots, proximal roots, shoot base, and proximal shoot) using NIH ImageJ $1.45 \mathrm{~s}$ software (Schneider et al. 2012). ROIs were manually selected on the image data and the time-activity curves (timecourses of signal intensity in the ROIs) were generated and used to estimate the dynamics of $\mathrm{Cd}$ in the culture solution, whole root apparatus, shoot base, and proximal shoot, as described by Yoshihara et al. (2014).

\section{Autoradiography}

At the end of the PETIS experiments, plants were dissected, fixed on paper sheets with adhesive tape, and then placed in contact with imaging plates (BASMS2040, GE Healthcare, Japan) in cassettes for 3 days. The imaging plates were scanned using a Bio Imaging Analyzer (Typhoon FLA 7000, GE Healthcare, Japan) to generate the autoradiographic images of ${ }^{109} \mathrm{Cd}$ in the plants. In fact, ${ }^{109} \mathrm{Cd}$ with a longer half-life (461 days) than ${ }^{107} \mathrm{Cd}(6.5 \mathrm{~h})$ was also obtained at a minor ratio (approximately 1:3000) in the production process of ${ }^{107} \mathrm{Cd}$.

\section{Statistical Analysis}

Statistical analysis was carried out using SigmaPlot for Windows version 11.0 (Systat Software, Inc., Chicago, IL, USA). Quantitative values are presented as mean \pm standard error of the mean (SE). Significance values were adjusted for multiple comparisons using the Bonferroni correction. Statistical significance was at $P<0.05$. Student's $t$-test was used to assess the significance of the observed differences between plants exposed or not to $\mathrm{Cd}$ in each $\mathrm{Zn}$ exposure condition analyzed. Statistical significance was at $P \leq 0.001$.

\section{Additional File}

Additional file 1: Table S1. Fractioning of $\mathrm{Zn}$ ions retained in root. Table S2 Fractioning of Cd ions retained in root. Table S3 Zn ions retained in the root in complexes with thiols. Table S4 $\mathrm{Cd}$ ions retained in the root in complexes with thiols. Figure S1 Relationship between $\mathrm{Zn}$ and $\mathrm{Cd}$ ions loaded in the xylem sap and $\mathrm{Zn}$ and $\mathrm{Cd}$ concentration in shoots. Figure S2 Fractioning of $\mathrm{Zn}$ and $\mathrm{Cd}$ ions in the buffer extract. Figure S3 Zn- and Cd-binding complexes resolved by gel filtration chromatography. Figure S4 Autoradiography and time-course analysis of $\mathrm{Cd}$ accumulation in the shoot base. Figure S5 Another set of time-course analysis of Cd systemic movement. (PDF $1.39 \mathrm{mb}$ )

\section{Abbreviations}

Cd: cadmium; DEAE: diethylaminoethyl cellulose; DTNB: 5,5'-dithiobis (2-nitrobenzoic acid); FOV: field of view; HMW: high-molecular-weight; ICPMS: inductively coupled plasma mass spectrometry; LMW: low-molecularweight; NPTs: non-protein thiols; PCs: phytochelatins; PETIS: positron-emitting tracer imaging system; ROIs: regions of interest; RT-PCR: reverse transcription polymerase chain reaction; Zn: zinc.

\section{Competing Interests}

The authors declare that they have no competing interests.

\section{Authors' Contributions}

$L F, C L, N S, S F, G A S$, and FFN conceived and designed the experiments. LF, $\mathrm{CL}, \mathrm{BD}, \mathrm{AF}$, and FFN carried out the physiological and biochemical analyses. GL performed ICP-MS analysis. LF, NS, Y-GY, SI, NK, and SF performed PETIS experiments. $C L$ and $G A S$ acquired the funds. $L F, A F$, and FFN wrote the manuscript. All authors discussed, revised and approved the manuscript.

\section{Acknowledgments}

This work was supported by grants from the Italian Ministry of Education, University, and Research (FIRB 2008 - PROGRAMMA "FUTURO IN RICERCA": Groundbreaking methods to study the mechanisms of mobilization and acquisition of trace metals in the soil-plant system; RBFR08L2ZT), and the Project AGER Risinnova (grant No. 2010-2369).

We thank Prof Yohey Hashimoto for having had Laura Fontanili as a guest in the framework of the Agreement of Scholarly Exchange and Collaboration between UNIMI (Università degli Studi di Milano) and TUAT (Tokyo University of Agriculture and Technology). We thank Prof Maurizio Cocucci for his valuable contribution during the writing of this paper.

The music of Karlheinz Stockhausen inspired this work.

\section{Author details}

'Dipartimento di Scienze Agrarie e Ambientali - Produzione, Territorio, Agroenergia (DISAA), Università degli Studi di Milano, 20133 Milan, Italy. ${ }^{2}$ Istituto di Biologia e Biotecnologia Agraria (IBBA), Consiglio Nazionale delle Ricerche, 20133 Milan, Italy. ${ }^{3}$ Department of Radiation-Applied Biology, Takasaki Advanced Radiation Research Institute, Quantum Beam Science Research Directorate, National Institutes for Quantum and Radiological Science and Technology (QST), 1233 Watanuki, Takasaki, Gunma 370-1292, Japan.

Received: 22 September 2015 Accepted: 2 April 2016 Published online: 12 April 2016 


\section{References}

Alloway BJ, Steinnes E (1999) Anthropogenic addition of cadmium to soils. In: McLaughlin MJ, Singh BR (eds) Cadmium in Soil and Plants. Kluwer Academic Publishers, Dordrecht, The Netherlands, pp 97-123

Arao T, Ae N (2003) Genotypic variations in cadmium levels of rice grain. Soil Sci Plant Nutr 49:473-479

Arao T, Ishikawa S, Murakami M, Abe K, Maejima Y, Makino T (2010) Heavy metal contamination of agricultural soil and countermeasures in Japan. Paddy Water Environ 8:247-257

Cai S, Yue L, Hu Z, Zhong X, Ye Z, Xu H, Liu YR, Ji RD, Zhang WH, Zhang F (1990) Cadmium exposure and health effects among residents in an irrigation area with ore dressing wastewater. Sci Total Environ 90:67-73

Chaney RL (2010) Cadmium and zinc. In: Hooda PS (ed) Trace Elements in Soils. John Wiley \& Sons Ltd, Chichester, UK, pp 409-439

Chaney RL (2015) How does contamination of rice soils with Cd and Zn cause high incidence of human $\mathrm{Cd}$ disease in subsistence rice farmers. Curr Pollution Rep 1:13-22

Clemens S (2006) Toxic metal accumulation, responses to exposure and mechanisms of tolerance in plants. Biochimie 88:1707-1719

Clemens S, Aarts MGM, Thomine S, Verbruggen N (2013a) Plant science: the key to preventing slow cadmium poisoning. Trends Plant Sci 18:2

Clemens S, Deinlein U, Ahmadi A, Höreth S, Uraguchi S (2013b) Nicotianamine is a major player in plant Zn homeostasis. Biometals 26:623-632

CODEX STAN 193-1995 (2015) General standard for contaminants and toxins in foods and feed. http://www.fao.org/fao-whocodexalimentarius/download/ standards/17/CXS_193e2015.pdf. Accessed 8 Apr 2016.

Colangelo EP, Guerinot ML (2006) Put the metal to the petal: metal uptake and transport throughout plants. Curr Opin Plant Biol 9:322-330

Deinlein U, Weber M, Schmidt H, Rensch S, Trampczynska A, Hansen TH, Husted S, Schjoerring JK, Talke IN, Krämer U, Clemens S (2012) Elevated nicotianamine levels in Arabidopsis halleri roots play a key role in zinc hyperaccumulation. Plant Cell 24:708-723

EFSA (2009) Cadmium in food - scientific opinion of the panel on contaminants in the food chain. EFSA J 980:1-139

Ellis KJ, Vartsky D, Zanzi I, Cohn SH, Yasumura S (1979) Cadmium: in vivo measurement in smokers and nonsmokers. Science 205:323-325

Fahad S, Hussain S, Khan F, Wu C, Saud S, Hassan S, Ahmad N, Gang D, Ullah A, Huang J (2015) Effects of tire rubber ash and zinc sulfate on crop productivity and cadmium accumulation in five rice cultivars under field conditions. Environ Sci Pollut Res 22:12424-12434

FAO/WHO (2001) Evaluation of certain food additives and contaminants. http:// whqlibdoc.who.int/trs/WHO_TRS_901.pdf.

Fox MRS (1988) Nutritional factors that may influence bioavailability of cadmium. J Environ Qual 17:175-180

Fox MRS, Tao S-H, Stone CL, Fry BE Jr (1984) Effects of zinc, iron, and copper deficiencies on cadmium in tissues of Japanese quail. Environ Health Perspect 54:57-65

Fujimaki S, Suzui N, Ishioka NS, Kawachi N, Ito S, Chino M, Nakamura S (2010) Tracing cadmium from culture to spikelet: noninvasive imaging and quantitative characterization of absorption, transport, and accumulation of cadmium in an intact rice plant. Plant Physiol 152:1796-1806

García-García JD, Girard L, Hernández G, Saavedra E, Pardo JP, Rodríguez-Zavala JS, Encalada R, Reyes-Prieto A, Mendoza-Cózatl DG, Moreno-Sánchez R (2014) Zn-bis-glutathionate is the best co-substrate of the monomeric phytochelatin synthase from the photosynthetic heavy metal-hyperaccumulator Euglena gracilis. Metallomics 6:604-616

Grant CA, Clarke JM, Duguid S, Chaney RL (2008) Selection and breeding of plant cultivars to minimize cadmium accumulation. Sci Total Environ 390: 301-310

Grill E, Winnacker EL, Zenk MH (1987) Phytochelatins, a class of heavy-metalbinding peptides from plants, are functionally analogous to metallothioneins. Proc Natl Acad Sci U S A 84:439-443

Grill E, Thumann J, Winnacker EL, Zenk M (1988) Induction of heavy-metal binding phytochelatins by inoculation of cell cultures in standard media. Plant Cell Rep 7:375-378

Haydon MJ, Kawachi M, Wirtz M, Hillmer S, Hell R, Krämer U (2012) Vacuolar nicotianamine has critical and distinct roles under iron deficiency and for zinc sequestration in Arabidopsis. Plant Cell 24:724-737

Honma Y, Hirata H (1978) Noticeable increase in cadmium absorption by zinc deficient rice plants. Soil Sci Plant Nutr 14:295-297

Ishikawa S, Suzui N, Ito-Tanabata S, Ishii S, Igura M, Abe T, Kuramat M, Kawachi N, Fujimaki S (2011) Real-time imaging and analysis of differences in cadmium dynamics in rice cultivars (Oryza sativa) using positron-emitting ${ }^{107} \mathrm{Cd}$ tracer. BMC Plant Biol 11:172

Ishikawa S, Yasuhiro Ishimaru Y, Igura M, Kuramata M, Abe T, Senoura T, Hased Y, Arao T, Nishizawa NK, Nakanishi H (2012) lon-beam irradiation, gene identification, and marker-assisted breeding in the development of lowcadmium rice. Proc Natl Acad Sci U S A 109:19166-19171

Kato M, Ishikawa S, Inagaki K, Chiba K, Hayashi H, Yanagisawa S, Yoneyama T (2010) Possible chemical forms of cadmium and varietal differences in cadmium concentrations in the phloem sap of rice plants (Oryza sativa L.). Soil Sci Plant Nutr 56:839-847

Kobayashi J (1978) Pollution by cadmium and the itai-itai disease in Japan. In: Oehme FW (ed) Toxicity of Heavy Metals in the Environment. Marcel Dekker, Inc, New York, pp 199-260

Kobayashi E, Okubo Y, Suwazono Y, Kido T, Nogawa K (2002) Dose-response relationship between total cadmium intake calculated from cadmium concentration in rice collected from each household of farmers and renal dysfunction in inhabitants of the Jinzu River basin, Japan. J Appl Toxicol 22: 431-436

Kobayashi NI, Tanoi K, Hirose A, Nakanishi TM (2013) Characterization of rapid intervascular transport of cadmium in rice stem by radioisotope imaging. J Exp Bot 64:507-517

Krotz RM, Evangelou BP, Wagner GJ (1989) Relationships between cadmium, zinc, Cdpeptide, and organic acid in tobacco suspension cells. Plant Physiol 91:780-787

Lee S, Persson DP, Hansen TH, Husted S, Schjoerring JK, Kim Y-S, Jeon US, Kim YK, Kakei Y, Masuda H, Nishizawa NK, An G (2011) Bio-available zinc in rice seeds is increased by activation tagging of nicotianamine synthase. Plant Biotechnol J 9:865-873

Makino T, Takano H, Kamiya T, Itou T, Sekiya N, Inahara M, Sakurai Y (2008) Restoration of cadmium-contaminated paddy soils by washing with ferric chloride: $\mathrm{Cd}$ extraction mechanism and bench-scale verification. Chemosphere 70:1035-1043

McKenna IM, Chaney RL, Tao S, Leach RM Jr, Williams FM (1992) Interactions of plant zinc and plant species on the bioavailability of plant cadmium to Japanese quail fed lettuce and spinach. Environ Res 57:73-87

McLaughlin M, Parker DR, Clarke JM (1999) Metals and micronutrients - food safety issues. Field Crops Res 60:143-163

Miyadate H, Adachi S, Hiraizumi A, Tezuka K, Nakazawa N, Kawamoto T, Katou K, Kodama I, Sakurai K, Takahashi H, Satoh-Nagasawa N, Watanabe A, Fujimura T, Akagi H (2011) OsHMA3, a $\mathrm{P}_{1 \mathrm{~B}}$-type of ATPase affects root-to-shoot cadmium translocation in rice by mediating efflux into vacuoles. New Phytol 189:190-199

Murakami M, Ae N, Ishikawa S (2007) Phytoextraction of cadmium by rice (Oryza sativa L.), soybean (Glycine max (L.) Merr.), and maize (Zea mays L.). Environ Pollut 145:96-103

Nakanishi H, Ogawa I, Ishimaru Y, Mori S, Nishizawa NK (2006) Iron deficiency enhances cadmium uptake and translocation mediated by the $\mathrm{Fe}^{2+}$ transporters OsIRT1 and OsIRT2 in rice. Soil Sci Plant Nutr 52:464-469

Nocito FF, Lancilli C, Dendena B, Lucchini G, Sacchi GA (2011) Cadmium retention in rice roots is influenced by cadmium availability, chelation and translocation. Plant Cell Environ 34:994-1008

Oliver DP, Hannam R, Tiller KG, Wilhelm N, Merry RH (1994) The effects of zinc fertilization on cadmium concentration in wheat grain. J Environ Qual 23:705-711

Olsen LI, Palmgren MG (2014) Many rivers to cross: the journey of zinc from soil to seed. Front Plant Sci 5:30

Perry HM, Tipton $H$, Schroeder HA, Steiner RL, Cook MJ (1961) Variation in the concentration of cadmium in human kidney as a function of age and geographic origin. J Chron Dis 14:259-271

Ramesh SA, Shin R, Eide DJ, Schachtman DP (2003) Different metal selectivity and gene expression of two zinc transporters from rice. Plant Physiol 133:126-134

Rauser WE (1987) Compartmental efflux analysis and removal of extracellular cadmium from roots. Plant Physiol 85:62-65

Rauser WE, Meuwly P (1995) Retention of cadmium in roots of maize seedlings. Role of complexation by phytochelatins and related thiol peptides. Plant Physiol 109:195-202

Reeves PG, Chaney RL (2004) Marginal nutritional status of zinc, iron, and calcium increases cadmium retention in the duodenum and other organs of rats fed a rice-based diet. Environ Res 96:311-322

Rodda MS, Li G, Reid RJ (2011) The timing of grain Cd accumulation in rice plants: the relative importance of remobilisation within the plant and root Cd uptake post-flowering. Plant Soil 347:105-114

Sasaki A, Yamaji N, Yokosho K, Ma JF (2012) Nramp5 is a major transporter responsible for manganese and cadmium uptake in rice. Plant Cell 24:2155-2167 
Satoh-Nagasawa N, Mori M, Nakazawa N, Kawamoto T, Nagato Y, Sakurai K, Takahashi H, Watanabe A, Akagi H (2012) Mutations in rice (Oryza sativa) heavy metal ATPase 2 (OsHMA2) restrict the translocation of zinc and cadmium. Plant Cell Physiol 53:213-224

Satoh-Nagasawa N, Mori M, Sakurai K, Takahashi H, Watanabe A, Akagi H (2013) Functional relationship heavy metal P-type ATPases (OsHMA2 and OsHMA3) of rice (Oryza sativa) using RNAi. Plant Biotechnol 30:511-515

Schneider CA, Rasband WS, Eliceiri KW (2012) NIH Image to ImageJ: 25 years of image analysis. Nat Methods 9:671-675

Shi J, Li L, Pan G (2009) Variation of grain Cd and Zn concentrations of 110 hybrid rice cultivars grown in a low-Cd paddy soil. J Environ Sci 21:168-172

Simmons RW, Pongsakul P, Chaney RL, Saiyasitpanich D, Klinphoklap S, Nobuntou W (2003) The relative exclusion of zinc and iron from rice grain in relation to rice grain cadmium as compared to soybean: Implications for human health. Plant Soil 257:163-170

Sinclair SA, Krämer U (2012) The zinc homeostasis network of land plants. Biochim Biophys Acta 1823:1553-1567

Song WY, Mendoza-Cózatl DG, Lee Y, Schroeder Jl, Ahn SN, Lee HS, Wicker T, Martinoia E (2014) Phytochelatin-metal(loid) transport into vacuoles shows different substrate preferences in barley and Arabidopsis. Plant Cell Environ 37:1192-1201

Souza JF, Rauser WE (2003) Maize and radish sequester excess cadmium and zinc in different ways. Plant Sci 165:1009-1022

Takahashi R, Ishimaru Y, Senoura T, Shimo H, Ishikawa S, Arao T, Nakanishi H, Nishizawa NK (2011) The OsNRAMP1 iron transporter is involved in Cd accumulation in rice. J Exp Bot 62:4843-4850

Takahashi R, Ishimaru Y, Shimo H, Ogo Y, Senoura T, Nishizawa NK, Nakanishi H (2012) The OsHMA2 transporter is involved in root-to-shoot translocation of Zn and Cd in rice. Plant Cell Environ 35:1948-1957

Tanaka K, Fujimaki S, Fujiwara T, Yoneyama T, Hayashi H (2007) Quantitative estimation of the contribution of the phloem in cadmium transport to grains in rice plants (Oryza sativa L.). Soil Sci Plant Nutr 53:72-77

Tennstedt P, Peisker D, Böttcher C, Trampczynska A, Clemens S (2009) Phytochelatin synthesis is essential for the detoxification of excess zinc and contributes significantly to the accumulation of zinc. Plant Physiol 149:938-948

Ueno D, Yamaji N, Kono I, Huang CF, Ando T, Yano M, Ma JF (2010) Gene limiting cadmium accumulation in rice. Proc Natl Acad Sci U S A 107:16500-16505

Uraguchi S, Fujiwara T (2013) Rice breaks ground for cadmium-free cereals. Curr Opin Plant Biol 16:328-334

Uraguchi S, Mori S, Kuramata M, Kawasaki A, Arao T, Ishikawa S (2009) Root-toshoot $\mathrm{Cd}$ translocation via the xylem is the major process determining shoot and grain cadmium accumulation in rice. J Exp Bot 60:2677-2688

Uraguchi S, Kamiya T, Sakamoto T, Kasai K, Sato Y, Nagamura Y, Yoshida A, Kyozuka J, Ishikawa S, Fujiwara T (2011) Low-affinity cation transporter (OsLCT1) regulates cadmium transport into rice grains. Proc Natl Acad Sci U S A 108:20959-20964

Wagner GJ (1993) Accumulation of cadmium in crop plants and its consequences to human health. Adv Agron 51:173-212

Wong CK, Cobbett CS (2009) HMA P-typeATPases are the major mechanism for root-to-shoot Cd translocation in Arabidopsis thaliana. New Phytol 181:71-78

Yamaguchi N, Ishikawa S, Abe T, Baba K, Arao T, Terada Y (2012) Role of the node in controlling traffic of cadmium, zinc, and manganese in rice. J Exp Bot 63: 2729-2737

Yamaji N, Xia J, Mitani-Ueno N, Yokosho K, Ma JF (2013) Preferential delivery of zinc to developing tissues in rice is mediated by P-type heavy metal ATPase OsHMA2. Plant Physiol 162:927-939

Yoshihara T, Suzui N, Ishii S, Kitazaki M, Yamazaki H, Kitazaki K, Kawachi N, Yin YG, Ito-Tanabata S, Hashida SN, Shoji K, Shimada H, Goto F, Fujimaki S (2014) A kinetic analysis of cadmium accumulation in a Cd hyper-accumulator fern, Athyrium yokoscense and tobacco plants. Plant Cell Environ 37:1086-1096

Zenk MH (1996) Heavy metal detoxification in higher plants - a review. Gene 179:21-30

\section{Submit your manuscript to a SpringerOpen ${ }^{\mathcal{O}}$ journal and benefit from:}

- Convenient online submission

- Rigorous peer review

- Immediate publication on acceptance

- Open access: articles freely available online

- High visibility within the field

- Retaining the copyright to your article

Submit your next manuscript at $\boldsymbol{s p r i n g e r o p e n . c o m ~}$ 